\title{
Luke 2:22, Leviticus 12, and Parturient Impurity ${ }^{1}$
}

\author{
Matthew Thiessen \\ Saskatoon, Saskatchewan
}

\begin{abstract}
In Luke 2:22 Luke attributes parturient impurity to both Mary and Jesus (and/or Joseph). Interpreters have often concluded that this verse demonstrates that Luke misunderstands the levitical legislation pertaining to childbirth impurity (Leviticus 12), which discusses only the impurity of the new mother. This article argues that, despite the apparent contradiction between Leviticus 12 and Luke 2, Luke has not misunderstood Jewish conceptions of impurity after birth. Not only is it possible to conclude that Leviticus 12 implicitly ascribes impurity to the newborn child, but some Second Temple Jewish writers, such as the authors of Jubilees and 4Q265, also believed that the newborn child suffered the same manner of impurity as the new mother. Luke's gospel, therefore, demonstrates familiarity with contemporary Jewish purity beliefs and practices.
\end{abstract}

\section{Keywords}

Luke; Leviticus 12; Jubilees; 4Q265; impurity; parturient

\section{Introduction}

And when the days of their purification were completed according to the law of Moses

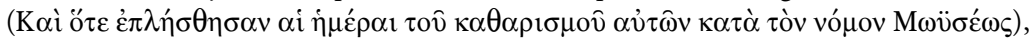
they brought him to Jerusalem to present him to the Lord (as it is written in the law of the Lord, "Every male who opens the womb shall be called holy to the Lord") and to offer a sacrifice according to what is said in the law of the Lord, "a pair of turtledoves or two young pigeons" (Luke 2:22-24).

Any woman who conceives and gives birth to a male will be impure seven days; according to the days of the separation of her menstruation she will be impure.... And thirty-three days she will remain in her impure blood. She will neither touch anything holy nor enter into the sanctuary until the days of her purification are completed

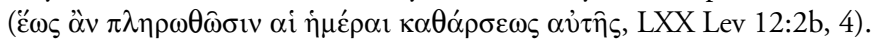

1) I would like to thank David M. Moffitt for his helpful comments on an earlier draft of this article. 
Luke's story of the presentation of Jesus in the Jerusalem Temple raises more questions than it answers. Raymond Brown summarizes the problems inherent in the account: "Imprecisely Luke seems to think that both parents needed to be purified ('their purification' in 2:22), that the child needed to be brought to Jerusalem to be presented to the Lord (2:22-23), and that the offering of two young pigeons was related to the presentation (2:24 in sequence to $2: 22 \mathrm{~b}) .{ }^{2}$ According to the scholarly consensus, Luke's belief that both Mary and Joseph [and/or Jesus, a possibility that Brown does not mention] need to undergo purification conflicts with levitical law, which requires only the purification of the new mother (Lev 12:1-8). ${ }^{3}$ With regard to these issues Joseph B. Tyson states: "Here Luke probably misunderstood passages in the Hebrew Scriptures, as well as Jewish practices, since he conflated two different religious duties and failed to mention the practice of redeeming the first-born son." ${ }^{4}$

The purpose of this article is to question the seeming consensus that Luke has misunderstood Jewish purity laws dealing with childbirth. First, I will show that readers of the priestly legislation pertaining to purification

2) Brown, "The Presentation of Jesus (Luke 2:22-40)," Worship 51 (1977) 2-11 (3). Brown is not alone in concluding that Luke here demonstrates his lack of knowledge of Jewish customs. See H. Räisänen, Die Mutter Jesu im Neuen Testament (AASF 247; Helsinki: Suomalainen Tiedeakatemia, 1989) 127; E. Klostermann, Das Lukasevangelium (3rd ed.; HAT 5; Tübingen: Mohr [Siebeck], 1975) 41; J. Mann, "Rabbinic Studies in the Synoptic Gospels, II: The Redemption of a First-Born Son and the Pilgrimages to Jerusalem," HUCA 1 (1924) 323-355; R. Bultmann, Die Geschichte der Synoptischen Tradition (10th ed.; Göttingen: Vandenhoeck \& Ruprecht, 1995) 326; G. Schneider, Das Evangelium nach Lukas, Kapitel 1-10 (ÖKT 3/1; Gütersloh: Gütersloh, 1992) 71; M. Soards, "Luke 2:22-40," Int 44.4 (1990) 400-405 (401); J.A. Fitzmyer, The Gospel According to Luke (I-IX): Introduction, Translation, and Notes (AB 28; Garden City, N.Y.: Doubleday, 1981) 424; R.H. Stein, Luke (NAC 24; Nashville: Broadman, 1992) 113; C.F. Evans, Saint Luke (TPINTC; Philadelphia: Trinity Press International, 1990) 212; F. Bovon, A Commentary on the Gospel of Luke 1:1-9:50 (Hermeneia; Minneapolis: Fortress, 2002) 99; J. Nolland, Luke 1-9:20 (WBC 35a; Dallas: Word Books, 1989) 117; and I.H. Marshall, The Gospel of Luke: A Commentary on the Greek Text (NIGTC; Grand Rapids, Mich.: Eerdmans, 1978) 116.

3) For example, Fitzmyer (Luke, 424) and Nolland (Luke, 117) conclude that "their" $(\alpha \dot{\tau} \tau \hat{\omega} v)$ refers to Joseph and Mary, while Origen (Homilies on Luke 14.3-6) believes $\alpha \dot{v} \tau \hat{\omega} v$ refers to Mary and Jesus. Although a number of Christian interpreters of Leviticus refer to Luke 2:22, they do not discuss the fact that Leviticus 12 mentions only "her purification," while Luke 2:22 mentions "their purification." See, for instance, J.E. Hartley, Leviticus (WBC 4; Dallas: Word Books, 1992) 170, and S.E. Balentine, Leviticus (Interpretation; Louisville: John Knox, 1989) 104.

4) Tyson, Marcion and Luke-Acts: A Defining Struggle (Columbia, S.C.: University of South Carolina Press, 2006) 99. 
after childbirth could conclude that either the newborn or someone else might become impure from a parturient; second, I will show that at least some Second Temple Jews did believe that infants were born ritually impure. Before doing so, though, the textual evidence of Luke 2:22 must be considered.

\section{Early Christian Corrections of Luke 2:22}

According to the 27th edition of Nestle-Aland, the Greek text of

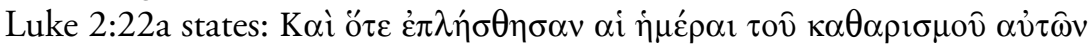

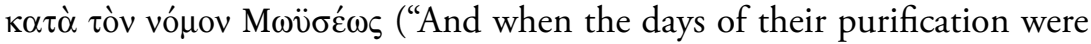
completed, according to the law of Moses"). The manuscript evidence demonstrates that early Christian scribes considered Luke's statement problematic. While the majority of witnesses contain the plural pronoun $\alpha \hat{v} \tau \hat{\omega} v$ (including $\aleph, \mathrm{A}, \mathrm{B}, \mathrm{L}, \mathrm{W}, \Lambda, \Delta, \Gamma, \Pi$, most miniscules, the Peshitta, Ethiopic, Armenian, Gothic, and Origen), a number of non-Greek witnesses attest to the third person feminine singular pronoun $\alpha \hat{\tau} \tau \hat{\varsigma} \varsigma$, other manuscripts have the third person singular pronoun $\alpha$ vov $(\mathrm{D}$, and various miniscules), and still other manuscripts contain no genitive pronoun qualifying the word $\kappa \alpha \theta \alpha \rho \iota \mu$ оv. ${ }^{5}$

The absence of a personal pronoun removes any problem in the text, suggesting that a scribe attempted to avoid the question of who required purification. ${ }^{6}$ Similarly, since manuscripts containing the feminine singu-

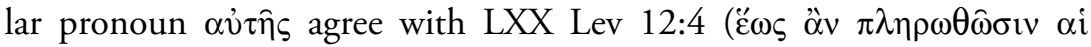

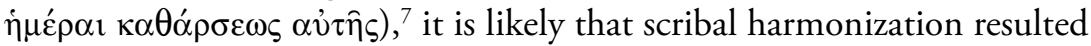

\footnotetext{
5) For the manuscript evidence, see American and British Committees of the International Greek New Testament Project, ed., The Gospel according to St. Luke, Part One: Chapters 1-12 (The New Testament in Greek 3; Oxford: Clarendon, 1984) 43, and W.H.P. Hatch, "The Text of Luke 2:22," HTR 14.4 (1921) 377-381.

6) It is also possible that a scribe who knew the Hebrew of Lev 12:4 took the unpointed Hebrew phrase ימי טהרה, not as "the days of her purification," but as "the days of purification," since one could interpret טהרה as a feminine noun, and not as the masculine noun טהר with the third person feminine singular possessive suffix ה. If so, the scribe has harmonized Luke 2:22 with his reading of Lev 12:4. Compare the earlier occurrence of טהרה in Lev 12:4, which the MT points as a feminine noun (i.e., the final heh lacks a mappiq), but the LXX translates as $\dot{\alpha} \kappa \alpha \theta \dot{\alpha} \rho \tau \emptyset \alpha \dot{v} \tau \hat{\eta} \varsigma$. See the following note for the manuscript evidence to LXX Lev 12:4.

7) While there are a number of variants to this verse in mss of LXX Leviticus, all contain

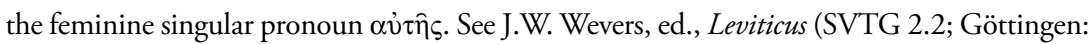
Vandenhoeck \& Ruprecht, 1986) 138-139. The MT reads עד מלאת ימי טהרה.
} 
in this reading. The remaining variants, $\alpha \dot{v} \tau o \hat{v}$ and $\alpha \dot{v} \tau \hat{\omega} v$, are difficult for two reasons. First, neither of these readings matches the priestly legislation on parturient impurity, which only mentions the mother's impurity. Second, readers could take either variant to suggest that Jesus suffered ritual impurity, an interpretation that likely would have troubled early scribes. ${ }^{8}$ Although both readings are equally theologically difficult, the early, diverse, and weighty external support for $\alpha \dot{v} \tau \hat{\omega} v$ suggests that it is an earlier reading than $\alpha \hat{v} \tau o v$. This conclusion suggests that the other variants ( $\alpha \dot{v} \tau \hat{\eta} \varsigma$ and no personal possessive pronoun) are attempts to lessen the discrepancy between Lev 12:4 and Luke 2:22.

Having determined which reading best accounts for the existence of other variants of Luke 2:22, I can now address the question of whether or not Luke misunderstands childbirth impurity.

\section{Leviticus 12:1-8 and Parturient Impurity}

According to the priestly legislation pertaining to childbirth, a woman

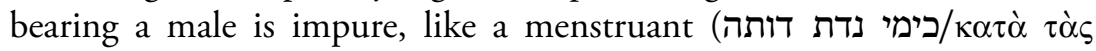

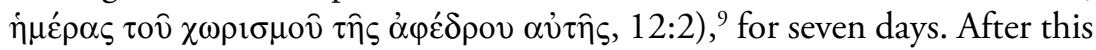
seven-day period, the male child undergoes circumcision and the mother's

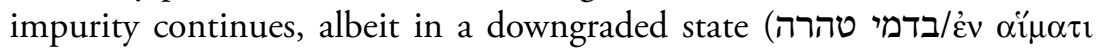
$\dot{\alpha} \kappa \alpha \theta \dot{\alpha} \rho \tau \omega \alpha \dot{\tau} \tau \hat{\jmath} \varsigma, 12: 4),{ }^{10}$ for an additional thirty-three days. In contrast, if the mother gives birth to a female, she bears a menstrual-like impurity that lasts for fourteen days, and then her downgraded impurity continues for a further sixty-six days. ${ }^{11}$ At the completion of this period, the mother

8) See A. Plummer, A Critical and Exegetical Commentary on the Gospel according to S. Luke (5th ed.; ICC; Edinburgh: T\&T Clark, 1922) 63. Even the possibility that Mary might be deemed impure was problematic for early Christian interpreters. For instance, despite Luke 2:22 Origen says of Leviticus 12, "For the Lawgiver added this word [i.e., "conceived"] to distinguish her who 'conceived and gave birth' without seed from other women so as not to designate as 'unclean' every woman who had given birth but her who 'had given birth by receiving seed'" (Homilies on Leviticus 8.2.2; translation of G.W. Barkley, Origen: Homilies on Leviticus [FOC 83; Washington, D.C.: Catholic University of America Press, 1990] 154).

9) As J. Milgrom (Leviticus 1-16: A New Translation with Introduction and Commentary [AB 3; New York: Doubleday, 1991] 744) notes, this phrase stresses "that the quality of the impurity and not just its length is equivalent to that of the menstruant (see 15:19-24)."

10) On the meaning of this phrase, see Milgrom (Leviticus 1-16, 749), who argues that this downgraded impurity excludes the woman only from sancta.

11) For a helpful depiction of these stages of impurity, see R. Whitekettle, "Leviticus 12 and 
must bring a lamb (a turtledove or pigeon if she is too poor) for a burnt offering (עלה), and a pigeon or turtledove for a purification offering (חטאת, Lev 12:6-8). During the period of impurity the new mother cannot touch holy things or enter Israel's sanctuary. ${ }^{12}$ Of Leviticus 12, Jacob Milgrom states: "The active agent in this chapter is solely the new mother. It is she who must scrupulously keep count of the days of her purification period and, at its termination, bring its requisite offerings." 13

Taking into account the singular attention that the priestly legislation pays to the mother, Milgrom asks the following question: "What of the Israelite child? Is he (or she) rendered impure by contact with the mother? The text is silent. Nor is there even a hint of an answer in Scripture. Does its silence mean that the newborn is exempt from the laws of nidda, or must we assume that the child's impurity is taken for granted, that the child is isolated with the mother during the seven (or fourteen) days, and that at the termination of this period it undergoes immersion with her? There is no clear answer." ${ }^{14}$

To be sure, Leviticus does not explicitly address the question of the purity or impurity of the newborn child. Yet the reader cannot take this silence as proof that the newborn child suffers no impurity. As Milgrom argues, Leviticus is not an exhaustive description of all the purity laws

the Israelite Woman: Ritual Process, Liminality, and the Womb," ZAW 107.3 (1995) 393408 (401).

12) Scholars debate the reason why Leviticus excludes new mothers from sancta. G.J. Wenham (The Book of Leviticus [NICOT; Grand Rapids, Mich.: Eerdmans, 1979] 188) and Milgrom (Leviticus 1-16, 767) argue that the blood loss of childbirth aligns the experience with death, while D. Klee ("Menstruation in the Hebrew Bible," Ph.D. diss., Boston University, 1998), T. Frymer-Kensky ("Pollution, Purification, and Purgation in Biblical Israel," in The Word of God Shall Go Forth: Essays in Honor of David Noel Freedman in Celebration of His Sixtieth Birthday [ed. C.L. Meyers and M. O'Connor; Winona Lake, Ind.: Eisenbrauns, 1983] 399-414), and H. Maccoby (Ritual and Morality: The Ritual Purity System and its Place in Judaism [Cambridge: Cambridge University Press, 1999] 49-50) argue that childbirth is the experience of new life, which must be kept out of holy space. Either interpretation suggests that the mortality of humanity is the issue and that it is such mortality that cannot approach God. As D.P. Wright ("Unclean and Clean [OT]," ABD 6:729-741 [739]) states: "[T] he mortal condition is incompatible with God's holiness."

13) Milgrom, Leviticus 1-16, 743.

14) Milgrom, Leviticus 1-16, 746. In contrast, in his brief discussion of Luke 2:22, Milgrom (Leviticus 1-16, 762) states: "Leviticus leaves no room for doubt that only one person needs be purified: the new mother." See the similar remarks of B.A. Levine, Leviticus=Va-yikra: The Traditional Hebrew Text with the New JPS Translation (JPS Torah Commentary; Philadelphia: JPS, 1989) 72. 
enjoined upon Israel; rather, in it the priestly writer lays out a system of purity that is at times elliptical, requiring understanding of the whole in order to apply it appropriately to individual cases. ${ }^{15}$ Further, as Erhard S. Gerstenberger notes, even within Leviticus the legislation regarding parturition "is given an extraordinarily brief treatment." 16 This brevity leads to the omission of important information, for at the end of her initial sevenor fourteen-day period of impurity, Leviticus does not mention the way in which a woman removes this degree of impurity. Nonetheless, Milgrom argues that an ablution requirement is "omitted for the simple reason that it is taken for granted except in cases in which it is not self-understood."17 If in Leviticus 12 the priestly writer leaves unstated so central a rite to purification as immersion, it is conceivable that he omits other aspects of the purity legislation as well. In the conclusion of this article, I will discuss why I believe Leviticus does not mention the child's impurity and Luke's gospel does.

Cross-cultural parallels strengthen the possibility that Leviticus leaves unstated the assumption of the child's impurity. In ancient Egypt and Greece, for instance, the parturient and her newborn child both suffered ritual impurity. ${ }^{18}$ Just as Leviticus prescribes a lengthier period of impurity for the birth of a female than it does for a male, Hittite purity laws state that the male newborn and the mother remain impure for three months and the female newborn and the mother for four months. ${ }^{19}$

15) For a concise description of this system, see Milgrom, Leviticus 1-16, 976-1000. As M. Douglas (Leviticus as Literature [Oxford: Oxford University Press, 1999] 39) rightly states of the priestly literature: "Meanings are not carried primarily through verbal channels but conveyed obliquely by reference to established analogies."

16) Gerstenberger, Leviticus: A Commentary (OTL; Louisville: WJK, 1993) 147.

17) Milgrom, Leviticus 1-16, 756. As Milgrom notes, some early rabbis assumed ablutions at the end of this initial period of impurity and debated whether it was also required after the second stage of impurity (cf. m. Nid. 10.7).

18) A.M. Blackman, "Purification: Egypt," ERE 10:476-482 (477). For conceptions of birth impurity in Greece, see R. Parker, Miasma: Pollution and Purification in early Greek Religion (Oxford: Clarendon, 1983) 49-52, and T. Wächter, Reinheitsvorschriften im griechischen Kult (Giessen: Alfred Töpelmann, 1910) 25-36.

19) For further examples, see Milgrom, Leviticus 1-16, 763-765, and, more broadly, D.P. Wright, The Disposal of Impurity: Elimination Rites in the Bible and in Hittite and Mesopotamian Literature (SBLDS 101; Atlanta: Scholars, 1987). Additionally, the birth equipment and the midwife become impure. See G.M. Beckman, Hittite Birth Rituals (2d rev. ed.; Studien zu den Bogazköy-Texten 29; Wiesbaden: Otto Harrassowitz, 1983) 251. Gerstenberger (Leviticus, 148) notes that Leviticus 12 does not mention the impurity of midwives, but seems to assume it. 
Reading Leviticus, one could conclude that the newborn child was impure. First, that the purification period of the parturient differed on the basis of the gender of the newborn child suggests that the woman's impurity is related directly to the child. If the newborn does not suffer ritual impurity, why would its gender have any bearing on the length of the mother's purification process? Interpreters cannot adequately explain this correlation between the baby's gender and the length of the mother's impurity apart from positing the influence of the impurity of the child. ${ }^{20}$

Second, why does the circumcision of the male newborn take place on the eighth day after birth? Is it possible that the Priestly School believed that the male child suffered the same degree of impurity as the mother during the first seven days after birth and that circumcision needed to be delayed in order for this heightened level of impurity to pass?

Finally, Leviticus 12 twice likens the initial phase of impurity (the sevenday period after a male's birth, or the fourteen-day period after a female's birth) to the impurity of a menstruant (12:2-5; cf. Lev 15:19-24). ${ }^{21}$ Accordingly, if we are to understand parturient impurity, we must do so in light of the lengthier discussion of menstrual impurity. Of particular importance is Leviticus 15, which asserts that a male who lies with a woman during her menstruation contracts an impurity lasting seven days $(15: 24) .^{22}$

20) For attempts to explain this correlation scientifically, see D.I. Macht, "A Scientific Appreciation of Leviticus 12:1-5," JBL 52.4 (1933) 253-260, and J. Magonet, "'But if it a Girl, she is Unclean for Twice Seven Days...': The Riddle of Leviticus 12:5," in Reading Leviticus: A Conversation with Mary Douglas (ed. J.F.A. Sawyer; JSOTSup 227; Sheffield: Sheffield Academic, 1996) 144-152. In Questions and Answers on Genesis 1.25, Philo provides an ancient scientific explanation, arguing that the male embryo takes forty days to form, while the female embryo takes eighty days. Philo seems to be indebted here to wider Graeco-Roman thinking on the differing developmental periods of male and female embryos, as a comparison with the Hippocractic work On the Nature of the Child (18.1) demonstrates. See the discussion of I.M. Lonie, The Hippocratic Treatises, "On Generation," "On the Nature of the Child," "Diseases IV" (Berlin: de Gruyter, 1981) 192.

21) A. Dillmann (Das Bucher Exodus und Leviticus [KEH 12; Leipzig: Hirzel, 1888] 550) and K. Elliger (Leviticus [HAT 4; Tübingen: Mohr, 1966] 157) argue that Leviticus 12 was originally part of the legislation dealing with bodily emissions found in Leviticus 15 . While this suggestion has no textual support, it does recognize the important interconnections between the two chapters.

22) This impurity is only the case for accidental contact with menstrual blood. According to Lev 20:18, a man who knowingly has sexual intercourse with a menstruant is subject to the karet-penalty. See Milgrom, Leviticus 1-16, 940-941, and D.J. Wold, "The Kareth Penalty in P: Rational and Cases," in SBL Seminar Papers, 1979 (SBLSP 16; 2 vols.; Missoula, Mont.: Scholars, 1979) 1:1-45. 
As Jonathan Magonet argues, "the act of intercourse creates a single entity, 'one flesh', and both are equally affected by the status of uncleanness of the other." 23 This seven-day period of impurity contrasts with other forms of impurity contracted from the menstruant, which last only until evening (15:19-23). Since, unlike these other forms of contact, sexual intercourse with a menstruant brings about direct contact with menstrual blood, the woman's impurity is transmitted to the man (ותהי נדתה עליו, 15:24). Just as the menstruant suffers impurity for a seven-day period, so the man who has intercourse with her undergoes a seven-day period of impurity.

If parturient impurity is analogous to menstrual impurity, then presumably one contracts parturient impurity in the same manner. ${ }^{24}$ Direct contact with the blood of childbirth should result in an impurity similar to direct contact with menstrual blood. Consequently, although Leviticus does not state so explicitly, one could conclude that a person who contacts the blood of the parturient suffers the same impurity as that which the parturient endures - a seven- or fourteen-day period of impurity, followed by a lessened state of impurity lasting thirty-three or sixty-six days. As Magonet suggests, "[I]f any entity can be considered to be a 'single flesh' made up of two persons, it is a mother bearing a child." ${ }^{25}$ If this is the case, one cannot avoid the implication that the newborn child, having been in direct contact with both the mother's reproductive system and parturient blood at its birth, becomes impure in the same way as the mother, and like her, is thus in need of the same purification rites.

In light of both the Ancient Near Eastern context and the logic driving the legislation of the book of Leviticus, the reader cannot take the silence surrounding the question of the purity of a newborn in Lev 12:1-8 as evidence that the newborn existed outside the purity system.

\section{Parturient Impurity in the Second Temple Period}

Admittedly, the evidence of Leviticus does not demonstrate unequivocally that the newborn child requires purification. Nor does this silence help to determine the purification beliefs and ritual practices of Second Temple Jews. It is, therefore, necessary to determine whether or not evidence exists

\footnotetext{
23) Magonet, "But if it is a Girl," 151.

24) See also $11 Q T$ 48.15-17, which equates menstrual and parturient impurity.

25) Magonet, "But if it is a Girl," 151.
} 
that suggests that at least some Jews in this period believed that newborns suffered impurity.

The second-century в.C.E. book of Jubilees provides the first indication that Jews could conclude that newborns suffered ritual impurity. In his discussion of the creation of Adam and Eve, the author states:

\begin{abstract}
In the first week Adam and his wife-the rib-were created, and in the second week he [i.e., God] showed her to him. Therefore, a commandment was given to keep (women) in their defilement seven days for a male (child) and for a female two (units) of seven days. After 40 days had come to an end for Adam in the land where he had been created, we [i.e., the angels] brought him into the Garden of Eden to work and to keep it. His wife was brought (there) on the eightieth day. After this she entered the Garden of Eden. For this reason a commandment was written in the heavenly tablets for the one who gives birth to a child: if she gives birth to a male, she is to remain in her impurity for seven days like the first seven days; then for 33 days she is to remain in the blood of purification. She is not to touch any sacred thing nor to enter the sanctuary until she completes these days for a male. As for a female she is to remain in her impurity for two weeks of days like the first two weeks and 66 days in the blood of purification. Their total is 80 days. After she had completed these 80 days, we brought her into the Garden of Eden because it is the holiest in the entire earth, and every tree which is planted in it is holy. For this reason the law of these days has been ordained for the one who gives birth to a male or a female. She is not to touch any sacred thing nor to enter the sanctuary until the time when those days for a male or a female are completed $(3: 8-13) .{ }^{26}$
\end{abstract}

At first glance, Jubilees says nothing about the impurity of the newborn child. Yet one could take the narrative explanation that the author gives for these differing periods of impurity as evidence that the child itself undergoes a period of impurity. For the analogy between Adam and Eve and the parturient to make sense the reader must assume that both had undergone a period of impurity prior to their entry into the Garden. The author states that Adam was kept in "the land where he had been created" for forty days, and that Eve was kept out of the Garden until the end of an eighty-day period. He also claims that the Garden of Eden was the holiest place on earth, and that the trees in it were holy (3:12). In fact, in Jubilees Eden functions as the Temple: "[Noah] knew that the Garden of Eden is the holy of holies and is the residence of the Lord" (8:19). ${ }^{27}$ The only reason

26) Translation of Ethiopic comes from J.C. VanderKam, The Book of Jubilees: A Critical Edition (CSCO 511; Louvain: Peeters, 1989).

27) On the Garden of Eden as the Temple, see G.A. Anderson, "Celibacy or Consummation in the Garden? Reflections on Early Jewish and Christian Interpretations of the 
why the author would narrate the exclusion of Adam and Eve from this sanctum after their creation would be if he believed that, as "newborns," they suffered ritual impurity. Once time, in accordance with Lev 12:1-8, removed their newborn impurity, God permitted them entrance into the sanctum (that is, the Garden) and allowed them to touch the sancta (that is, every holy tree within it). As a result of this narration of the creation of Adam and Eve and their period of purification outside of the Garden, we can conclude that the author believed that newborns suffer the ritual impurity associated with childbirth. ${ }^{28}$

Similarly, 4Q265, while fragmentary, contains a mixture of laws with a narration of the creation of Adam and Eve. Joseph M. Baumgarten's reconstructed text demonstrates that this work, too, links God's placement of Adam and Eve in the Garden of Eden to the parturient legislation of Leviticus $12 .{ }^{29}$ Like Jubilees, the author of 4Q265 believes that the Garden and its trees are holy: "[For] the Garden of Eden is holy and all its young shoots are holy” (קיש [י] גן עדן וכול האב אשר בתוכו קודש], fragment 7, line 14). As Baumgarten states, "The entrance of Adam and Eve into the garden, after their respective periods of purification, can with little difficulty be viewed as paradigmatic for the acceptance of newly born infants of both sexes into the sacred sphere." 30

Both Jubilees and 4Q265 connect the creation of Adam and Eve, and their entry into Eden, to the laws of the parturient in Leviticus 12. Although neither work explicitly states that all subsequent newborn Israelites suffer childbirth impurity, this conclusion seems to be the logical result of the juxtaposition of levitical legislation and primeval narrative. Significantly,

Garden of Eden," HTR 82 (1989) 121-148 (129-131), C.T.R. Hayward, "The Figure of Adam in Pseudo-Philo's Biblical Antiquities," JSJ 23 (1992) 1-20 (6-7), and B. Ego, "Heilige Zeit-heiliger Raum—heiliger Mensch: Beobachtungen zur Struktur der Gesetzesbegründung in der Schöpfungs- und Paradiesgeschichte des Jubiläenbuchs," in Studies in the Book of Jubilees (ed. M. Albani, J. Frey, and A. Lange; TSAJ 65; Tübingen: Mohr Siebeck, 1997) 207-219 (214).

28) So, too, J.M. Baumgarten, "Purification after Childbirth and the Sacred Garden in 4Q265 and Jubilees," in New Qumran Texts and Studies: Proceedings of the First Meeting of the International Organization for Qumran Studies, Paris 1992 (ed. G.J. Brooke with F. García Martínez; STDJ 15; Leiden: Brill, 1994) 3-10, and H.K. Harrington, The Purity Texts (Companion to the Qumran Scrolls 5; London: T\&T Clark, 2004) 62, 100.

29) In addition to Baumgarten's article, "Purification after Childbirth," see also his critical edition with commentary, "265. 4QMiscellaneous Rules," in Qumran Cave 4, XXV: Halakhic Texts (ed. J. Baumgarten et al.; DJD XXXV; Oxford: Clarendon, 1999) 57-78.

30) Baumgarten, "Purification after Childbirth," 5. 
the ninth-century C.E. Byzantine chronicler George Syncellus, makes this connection:

For this reason, that is on account of the days of their separation from Paradise after their creation, God ordained through Moses in Leviticus that in giving birth to a male, a woman is impure for forty days, in giving birth to a female, for eighty days. For since Adam was introduced into Paradise on the fortieth day after he was formed, for this reason they also introduce male children that are born into the temple on the fortieth day, in accordance with the law. But in the case of a female child, God ordained that she is impure for eighty days, because of Eve's entrance into Paradise on the eightieth day, and because of the impurity of the female in relation to the male (Chronography 5)..$^{31}$

It appears that Syncellus wrongly attributes this passage to the Life of Adam; instead, it seems likely that he is actually citing a slightly different version of Jub. 3:8-13. ${ }^{32}$ Regardless, Syncellus preserves a compelling piece of evidence that some Jews in the Second Temple period believed that newborn infants suffered ritual impurity, just like their mothers.

I should stress that I am not arguing that all Jews in the Second Temple period concluded, on the basis of Leviticus 12, that newborns suffered childbirth impurity. 4Q266 provides the clearest evidence that this was not the case, since it forbids the new mother to nurse her child and requires the use of a wet nurse (4Q266 6 ii 10-11). The underlying assumption of this halakhah is that, if the mother nurses the newborn, she will convey impurity to her child. Thus, the author of 4Q266 agrees with Jubilees and

31) Translation taken from W. Adler and P. Tiffin, The Chronography of George Synkellos: A Byzantine Chronicle of Universal History from the Creation (Oxford: Oxford University Press, 2002).

32) W. Adler (Time Immemorial: Archaic History and Its Sources in Christian Chronography from Julius Africanus to George Syncellus [Dumbarton Oaks Studies 26; Washington, D.C.: Dumbarton Oaks Research Library and Collection, 1989] 85) argues that the Life of Adam to which Syncellus refers is a modified and enlarged account of Jubilees' version of the creation of Adam and Eve. For a detailed discussion of the relationship between Jubilees and the Life of Adam, see H. Gelzer (Sextus Julius Africanus und die byzantinische Chronographie [2 vols.; Leipzig: B.G. Teubner, 1885] 2:264-272), who concludes that this passage is an "Auszug aus dem Jubiläenbuch." Jean-Daniel Kaestli has kindly pointed out to me that one version of the Traditional Life of Adam and Eve contains a reference to the purification periods of Adam and Eve prior to their entry into the Garden, although this passage does not explicitly address the impurity of the newborn. J.H. Mozley ("The Vita Adae," JTS 30 [1929] 121-149 [124]) concludes that this passage's connection "with the 'Vita' dates at least to the eighth century, for it appears in the Paris MS of the ninth [century]." 
4Q265 in their belief that newborn children are susceptible to impurity, but disagrees with them regarding when (at the time of birth, or during the initial period of impurity) such transference of impurity occurs. As Martha Himmelfarb concludes: "[This] reading of the text of Leviticus is so persuasive that it is hard not to agree that $\mathrm{P}$ must have shared the view that the parturient conveyed impurity to those who touched her during the first stage of her impurity. Surely it would not have escaped P's notice that the newborn baby could not avoid such contact."33

\section{Conclusion: The Presentation of the Newborn Jesus in the Jerusalem Temple}

Despite the concern Jubilees and 4Q265 demonstrate over the possibility of the impurity of the newborn, Leviticus 12 does not address the child's status. Himmelfarb helpfully explains why this is so: "Leviticus 12 betrays no anxiety about this contact. Perhaps $P$ ignores the question because it does not think it important. The consequences of impurity as specified in Leviticus 12 are hardly relevant to a newborn, who is most unlikely to have the opportunity to enter the sanctuary or touch holy things and who is certainly incapable of eating sacrificial meat and other kinds of consecrated food." 34 Since Jubilees and 4Q265 narrate the entrance of Adam and Eve into the Garden of Eden, that is, into a sanctum, the authors of these works must make clear that Adam and Eve have completed the period of purification that Leviticus 12 requires. This observation is of utmost importance for the interpretation of Luke 2:22. Like Jubilees and 4Q265, but in contrast to Leviticus, Luke explicitly portrays the entrance of the newborn Jesus into sacred space when his parents present him to the Lord

\footnotetext{
33) Himmelfarb, "Impurity and $\operatorname{Sin}$ in 4QD, 1QS, and 4Q512," DSD 8.1 (2001) 9-37 (26).

34) Himmelfarb, "Impurity and Sin," 26. Himmelfarb's remarks are similar to the conclusions of W. Paschen (Rein und Unrein: Untersuchung zur biblischen Wortgeschichte [SANT 24; Munich: Kösel, 1970] 60), who argues that the parturient transmits impurity throughout the entire period of her purification. Interestingly, a late-second century Christian work, Protevangelium of James 5, claims that Mary's mother, Anna, gave birth to her but did not breastfeed her until she underwent purification. The author of this work shares with the author of 4Q266 the belief that a newborn child is susceptible to parturient impurity and attempts to protect Jesus' mother from this ritual impurity. The Canons of Hippolytus (see esp. Canon 18) demonstrate that in the fourth-century c.E. Christians still believed that childbirth brought about impurity, requiring the separation of both parturients and midwives from sacred space.
} 
(i.e., at the Jerusalem Temple). While the priestly writer of Leviticus did not need to address the purity status of the newborn, Luke is compelled to do so in order to portray Jesus in the temple precincts. Luke's infancy narrative stresses the law observance of Jesus' family (cf. 1:6, 9; 2:22-24, 27, 41-42); if he is not careful, he might implicate the infant Jesus in bringing ritual impurity into the sanctum.

This connection between Jesus' presentation in the temple and the need for the preceding purificatory rites explains one more of the three perceived errors Brown detects in Luke's understanding of the law. Brown argues that Luke wrongly conflates the childbirth sacrifices with temple presentation. ${ }^{35}$ But this combination of the legislation of Leviticus 12 with the presentation in the temple makes good halakhic sense. Since Luke portrays Jesus' parents presenting him to the Lord (an interpretive issue which I will not deal with here), he must ensure that his readers realize that all the requisite childbirth purificatory rites occurred prior to this presentation.

I have argued that Luke 2:22 contradicts neither the legislation of Leviticus 12 nor the childbirth practices of Luke's contemporary Jews. In fact, one could argue that Luke's views on childbirth impurity coincide with some of the stricter halakhic rulings on childbirth impurity in Second Temple Judaism. ${ }^{36}$ As a result, I would briefly like to touch upon the question of the identity of the author of Luke-Acts. In light of what he believes to be Luke's error regarding childbirth impurity, Brown concludes that the author of Luke was a Gentile convert to Christianity, perhaps a Gentile proselyte to Judaism prior to believing in Jesus, who only had "book knowledge" of Jewish customs. ${ }^{37}$ In similar fashion, although not excluding the possibility that Luke was a Diaspora Jew, Joseph Fitzmyer states: "What has to be recognized is that Luke, not being a Palestinian Jewish Christian, is not accurately informed about this custom of the purification of a woman after childbirth."38

\footnotetext{
35) Brown, "Presentation of Jesus," 3.

36) In Chapter Five of Contesting Conversion: Genealogy, Circumcision, and Identity in Ancient Judaism and Christianity (Oxford: Oxford University Press, 2011), I argue that Luke's halakhic rulings on circumcision also coincide with the strictest Second Temple period views on the rite.

37) Brown, "Presentation of Jesus," 4, n. 4. Similarly, M. Wolter (Das Lukasevangelium [HNT 5; Tübingen: Mohr Siebeck, 2008] 135) argues that Luke may have been influenced not by Jewish but by Greek conceptions of impurity.

38) Fitzmyer, Luke I-IX, 424.
} 
Neither Brown nor Fitzmyer rest their conclusion about Luke's nonJewish identity solely upon their belief that he was unfamiliar with Jewish childbirth rituals, yet clearly such supposed ignorance would support their conclusion. In contrast, I have argued that Luke does not display such ignorance. In fact, contrary to Brown, Luke does not display book knowledge of childbirth impurity, for if he did, he would conclude, following only the explicit instructions of the book of Leviticus, that the mother alone suffered impurity after giving birth. Luke goes beyond the written instruction of Leviticus 12, displaying a deeply knowledgeable understanding of impurity, one that comports with the book of Jubilees and 4Q265. Rather, it is later Christian scribes, who demonstrate their book knowledge of Leviticus by conforming Luke 2:22 to the explicit legislation of Leviticus 12. Of course, intimate knowledge of Jewish ritual legislation does not demonstrate that the author of Luke-Acts was a Jew. Nonetheless, perhaps the fact that Luke-Acts evidences sophisticated knowledge of ritual practice should cause us to reconsider long-cherished orthodoxies on the identity of Luke and his portrayal of Judaism and the Jewish Law. 